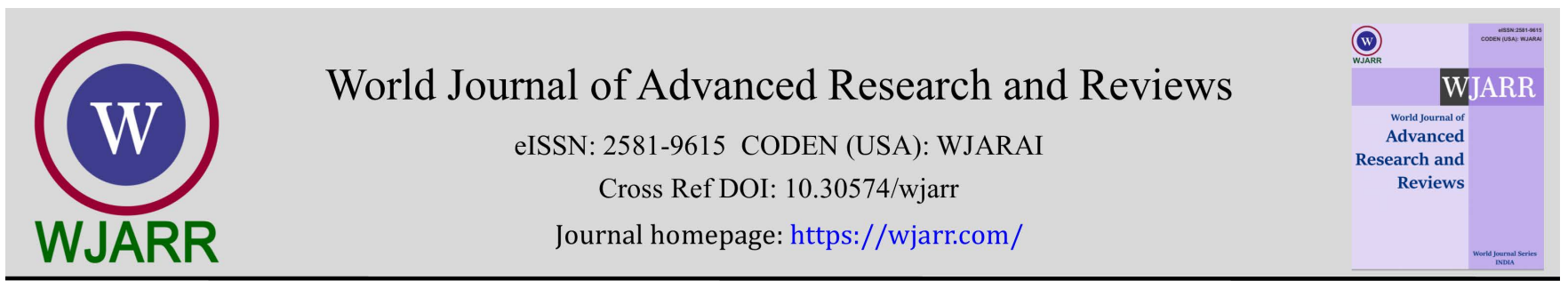

(RESEARCH ARTiClE)

\title{
Effect of planting methods on growth and yield of sweet potato (Ipomoea batatas L.) varieties at Luyengo, midlevel of Eswatini
}

\author{
Sakhile Sipho Dlamini, Mzwandile Petros Mabuza * and Bonginkhosi Edward Dlamini \\ Department of Crop Production, Faculty of Agriculture, University of Eswatini, P.O. Luyengo, Eswatini.
}

World Journal of Advanced Research and Reviews, 2021, 11(01), 013-021

Publication history: Received on 15 May 2021; revised on 02 July 2021; accepted on 06 July 2021

Article DOI: https://doi.org/10.30574/wjarr.2021.11.1.0281

\begin{abstract}
Sweet potato (Ipomoea batatas L.) is the most grown storage root crop in Eswatini. However, its storage root yield is low among smallholder farmers partly due to use of inappropriate varieties and agronomic practices such as planting method. Thus, a field experiment was conducted at the University of Eswatini, Faculty of Agriculture, Luyengo, during $2019 / 2020$ cropping season to determine the effects of planting method on growth and yield of the three sweet potato varieties. Two planting methods, namely horizontal and vertical; and three sweet potato varieties, namely Kenya-white, Ligwalagwala and Lamngititi were evaluated in a factorial arrangement in randomized complete block design in three replications. Results showed non-significant difference between the planting methods in most growth and yield parameters recorded for the sweet potato varieties. However, the vertical method of planting had relatively higher vine length, number of branches, mass of storage roots and storage root yield than the horizontal method. On the other hand, there were significant $(\mathrm{P}<0.05)$ differences among the sweet potato varieties for most of parameters recorded. The sweet potato variety Ligwalagwala had the highest vine length, number of storage roots per plant (6.47), mass of storage roots per plant (1137 g) and storage root yield (12.01 tonnes/ha). Thus, either horizontal or vertical method of planting and variety Ligwalagwala can be used to increase the productivity of sweet potato in the study area.
\end{abstract}

Keywords: Kenya-white; Lamngititi; Ligwalagwala; Planting method; Sweet potato

\section{Introduction}

Sweet potato (Ipomoea batatas L.) was originated in the South America low land with subsequent dispersed to the rest of the world between $15^{\text {th }}$ and $20^{\text {th }}$ century [1]. Asia is the world's largest sweet potato producing region with 88.51 million tonnes of annual production with China supplying about $76 \%$ of the world's production, making it the leading supplier of sweet potato in the world [2]. In sub Saharan Africa, sweet potato is the third most important root crop in production after cassava and yam where over 7 million tonnes ( $5 \%$ of global production) of sweet potato is produced annually [3]. Sweet potato is valued for its roots which are boiled, fried, baked or roasted for humans and the leaves are fed to livestock as a source of energy. The roots can also be processed into flour for bread making, starch for noodles as well as used as raw material for industrial starch and alcohol [4]. Sweet potato is the most important root crop after maize and common beans in Eswatini [5]. However, yields are generally low with an average storage root yield of 5 tonnes/ha [6] as compared to the world's average yield (11.8 t/ha) [7]. The low yield of sweet potato can be attributed to many constraints including biotic, abiotic and socio- economic factors. Use of inappropriate planting method and varieties contribute for low yield of sweet potato in Eswatini.

Planting methods of sweet potato have been reported to affect its growth and yield. Kunene [8]; and Pakkies et al. [9] obtained higher yields from the horizontal method of planting. However, Campbell [10] reported higher yields with the vertical method of planting.

\footnotetext{
${ }^{*}$ Corresponding author: Mzwandile Petros Mabuza

Department of Crop Production, Faculty of Agriculture, University of Eswatini, P.O. Luyengo, Eswatini..

Copyright $(2021$ Author(s) retain the copyright of this article. This article is published under the terms of the Creative Commons Attribution Liscense 4.0.
} 
Sweet potato varieties such as the Ligwalagwala (AVRDC1), Kenya-white (Ndlubu) and Lamngititi have been recommended for Eswatini. However, the effects of agronomic practices such as the planting methods have not been evaluated for some of the varieties. Depending on the experiences, farmers use different planting methods (horizontal and vertical method) without clear justification. Thus, this study was undertaken to determine the effects of planting methods on growth and yield of the three popular sweet potato varieties.

\section{Material and methods}

\subsection{Description of study area}

The experiment was carried out at the University of Eswatini, Faculty of Agriculture at Luyengo. Luyengo is Middleveld agro-ecological zone of Eswatini and located at $26.34^{\circ} \mathrm{S}$ and $31.10^{\circ} \mathrm{E}$ at an altitude of $732 \mathrm{~m}$ above sea level. The mean annual temperature is $18^{\circ} \mathrm{C}$ and an annual rainfall is between $800 \mathrm{~mm}$ to $1000 \mathrm{~mm}$. The soil type of the experimental site is the Malkerns M set soil series clay loam to sandy loam Oxisols mostly with acidic soil pH [11].

\subsection{Treatments and experimental design}

The treatments consisted of a factorial combinations of two planting methods (horizontal and vertical method), and three sweet potato varieties (Kenya-white, Ligwalagwala and Lamngititi). Kenya white is high yielding with a good storability. It can produce good yield in about four months. Ligwalagwala has a red skin with a cream white flesh. It needs five months to produce good yield. Lamngititi is little known in Eswatini. It has a purple to grey skin with a dark purple flesh. It also requires five months to mature. However, this variety is very low yielding. A randomised complete block design with three replications was used. Each plot was $4 \mathrm{~m}$ by $3.6 \mathrm{~m}$ with inter-row spacing of $90 \mathrm{~cm}$ and intrarow spacing of $25 \mathrm{~cm}$.

\subsection{Experimental field management}

The experimental field was ploughed, disked and ridged with a tractor. There were four ridges per plot. The $25 \mathrm{~cm}$ long vine cuttings of the three sweet potato varieties were subjected to the horizontal and vertical method of planting on the $5^{\text {th }}$ of December 2019. Fertilizer application of $350 \mathrm{~kg} / \mathrm{ha}$ of N: P: K [2:3:2 (22)] was done based on the recommendations of Ossom [12]. Fertilizer was applied as a single dosage during planting. Weeding and reshaping of ridges was carried out at 4 and 6 weeks after planting. The sweet potato was grown under rain-fed conditions. Harvesting of the two middle rows was done on the $4^{\text {th }}$ of April 2020.

\subsection{Data collected}

Vine length, number of branches and number of leaves were determined at 4, 6, 8, 10 and 12 weeks after planting from five randomly selected plants in each plot. The vine length was measured using a $5 \mathrm{~m}$ AIYI tape measure and the average of the five plants was recorded. Both the number of branches and number of leaves were counted manually and averages were recorded.

At harvesting, number of storage roots, mass of storage roots $(\mathrm{g})$, storage root diameter $(\mathrm{cm})$, length of storage roots $(\mathrm{cm})$ and storage root yield (tonnes/ha) were determined. The number of storage roots was determined by using five plants randomly selected from the net plot. Then from the total number of storage roots of each plot, average number of storage roots per plant of each plot was determined.

The mass of storage roots was determined from the already randomly selected five plants of the sweet potato from each plot. It was done using a $6 \mathrm{~kg}$ Contech high precision balance to determine the average mass of sweet potato storage roots per plant for each plot.

Storage root diameter was determined on the five randomly selected plants for number of storage roots and mass of storage roots using a stainless steel Vernier Caliper manufactured by Mitutoyo Co.(Japan). Diameter of all storage roots per plant was measured and the average for each plant was determined, then the average for each plot.

The length of storage roots was determined on the five plants used for determination of tuber diameter using a $300 \mathrm{~mm}$ ruler. The length of all storage roots from the five plants was measured and from that the average length per root was determined. The storage root yield was weighed immediately after harvest using a digital scale and the yield was converted to tonnes/ha. 


\subsection{Data Analysis}

Data collected were subjected analysis of variance using GENSTAT statistical package $18^{\text {th }}$ edition [13]. Significantly different treatment means were separated using Least Significant Difference (LSD) test at $5 \%$.

\section{Results}

\subsection{Vine length}

There was no significant difference in vine lengths between the two planting methods. At 4 weeks after planting (WAP), the horizontal planting had longer vines, however, from 6 to 12 WAP the vertical planting method had longer vine lengths (Table 1). The vertical method of planting had vine length of $155.7 \mathrm{~cm}$ whereas the horizontal method produced vine length of $140.7 \mathrm{~cm}$ when measured at the end, i.e. 12 WAP (Table 1).

There was a significant $(\mathrm{P}<0.05)$ difference in vine lengths among the varieties at all weeks of measurement. At all weeks of measurement, variety Ligwalagwala had significantly highest vine lengths while variety Kenya-white had the shortest vine (Table 1). At the last measurement (12 WAP), variety Ligwalagwala had the longest vines of $188.0 \mathrm{~cm}$ while variety Kenya-white had the shortest vine length of 113.cm (Table 1).

Table 1 Vine length $(\mathrm{cm})$ of sweet potato as affected by the planting methods and varieties at 4, 6, 8, 10 and 12 weeks after planting

\begin{tabular}{|c|c|c|c|c|c|}
\hline & \multicolumn{5}{|c|}{ Weeks after planting } \\
\hline Treatment & 4 & 6 & 8 & 10 & 12 \\
\hline \multicolumn{6}{|c|}{ Planting methods } \\
\hline Horizontal & 25.1 & 64.5 & 90.6 & 124.9 & 140.7 \\
\hline Vertical & 24.2 & 66.0 & 101.8 & 133.7 & 155.7 \\
\hline LSD (0.05) & ns & ns & ns & ns & ns \\
\hline \multicolumn{6}{|l|}{ Varieties } \\
\hline Kenya-white & $19.3 \mathrm{~b}$ & $43.5 \mathrm{c}$ & $69.6 \mathrm{~b}$ & $97.6 \mathrm{~b}$ & $113.1 \mathrm{c}$ \\
\hline Ligwalagwala & $34.4 \mathrm{a}$ & $92.0 \mathrm{a}$ & $129.9 a$ & $165.5 a$ & $188.0 \mathrm{a}$ \\
\hline Lamngititi & $20.2 \mathrm{~b}$ & $60.4 \mathrm{~b}$ & $89.0 \mathrm{~b}$ & $124.8 \mathrm{~b}$ & $143.5 b$ \\
\hline $\operatorname{LSD}(0.05)$ & 7.18 & 9.12 & 19.50 & 28.57 & 15.5 \\
\hline CV (\%) & 22.6 & 10.9 & 15.8 & 17.2 & 29.62 \\
\hline
\end{tabular}

\subsection{Number of branches}

There was no significant difference in the number of branches per plant between the horizontal and vertical method of planting from 4 to $10 \mathrm{WAP}$, however at $12 \mathrm{WAP}$, the vertical planting method had significantly $(\mathrm{P}<0.05)$ high number of branches (24.0) compared to the horizontal method of planting (18.9) (Table 2). There was no significant difference in

The number of branches per plant among the three sweet potato varieties, but variety Lamngititi had the highest number of branches per plant of 22.2 while variety Kenya-white had the lowest number of branches of 20.5 when determined at the end (Table 2). 
Table 2 Number of branches per plant of sweet potato in response to planting methods and varieties at 4, 6, 8, 10 and 12 weeks after planting

\begin{tabular}{|l|c|c|c|c|c|}
\hline \multicolumn{7}{|l|}{ Weeks after planting } \\
\hline Treatment & $\mathbf{4}$ & $\mathbf{6}$ & $\mathbf{8}$ & $\mathbf{1 0}$ & $\mathbf{1 2}$ \\
\hline Planting methods & 3.36 & 7.53 & 9.22 & 12.82 & $18.8 \mathrm{~b}$ \\
\hline Horizontal & 3.91 & 8.2 & 11.18 & 14.42 & $24.0 \mathrm{a}$ \\
\hline Vertical & $\mathrm{ns}$ & $\mathrm{ns}$ & $\mathrm{ns}$ & $\mathrm{ns}$ & 4.48 \\
\hline LSD (0.05) & & & & & \\
\hline Varieties & 4.27 & 7.53 & 10.3 & 13.1 & 20.5 \\
\hline Kenya-white & 3.13 & 7.6 & 9.87 & 12.83 & 21.7 \\
\hline Ligwalagwala & 3.5 & 8.47 & 10.43 & 14.93 & 22.2 \\
\hline Lamngititi & $\mathrm{ns}$ & $\mathrm{ns}$ & $\mathrm{ns}$ & $\mathrm{ns}$ & $\mathrm{ns}$ \\
\hline LSD (0.05) & 25.7 & 19.4 & 19.9 & 13.8 & 19.9 \\
\hline CV (\%) &
\end{tabular}

ns $=$ non-significant at $\mathrm{P}=0.05$; Means in columns followed by different letters are significantly Different from each other according to the Least Significance Difference; (LSD) test); CV = Coefficient of variation

\subsection{Number of leave}

There were significant $(\mathrm{P}<0.05)$ differences in the number of leaves per plant due to the interactions of planting methods and sweet potato varieties at 10 and 12 WAP (Figure 1). Variety Lamngititi in horizontal planting produced significantly highest number of leaves per plant of 203.5 and 251.3 while variety Ligwalagwala in horizontal planting had the lowest number of leaves per plant of 148.3 and 192.2 at 10 and 12 WAP, respectively (Figure 1). Both the main effects of planting method and varieties as well as their interaction had no significant effect on the number of leaves per plant at 4, 6 and 8 WAP.

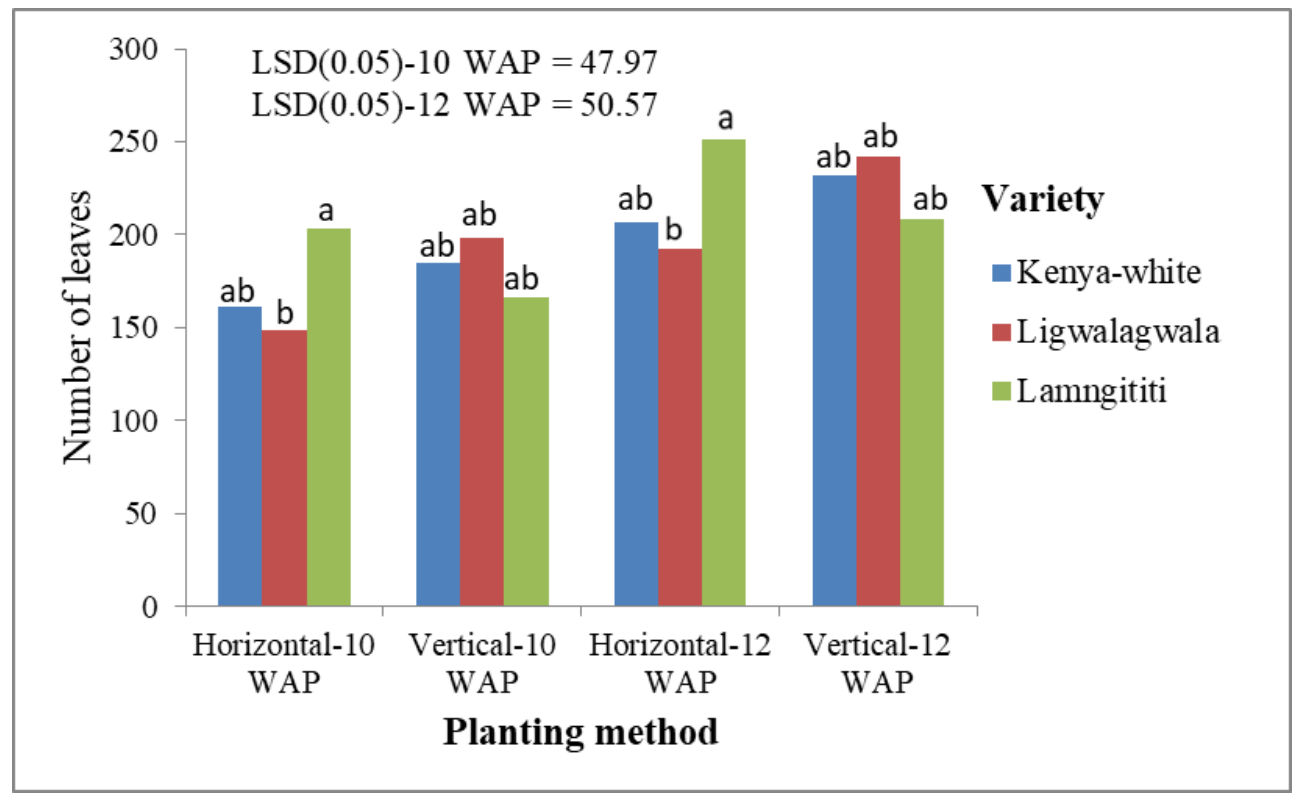

Figure 1 Number of leaves per plant of sweet potato in response to the interaction effect of planting methods and varieties at 10 and 12 weeks after planting

Means in bars within same weeks followed by same letters are not significantly different from each other according to the Least Significance Difference (LSD) test at 5\%. 


\subsection{Number of storage roots}

There was no significant difference in the number of storage roots per plant of the two planting methods (Table 3). The horizontal method of planting had higher number of storage roots per plant (5.89) as compared to the vertical method (5.56). However, there was a significant $(\mathrm{P}<0.05)$ difference among the three sweet potato varieties in the number of storage roots per plant. Varieties Ligwalagwala and Lamngititi had significantly $(\mathrm{P}<0.05)$ higher number of storage roots per plant of 6.47 and 6.33, respectively, than variety Kenya-white (Table 3).

\subsection{Fresh mass of storage roots}

Fresh mass of storage roots per plant was not significantly affected by the planting methods (Table 3). However, the mass of storage roots was higher $(1103 \mathrm{~g})$ on the vertical method of planting than the horizontal method of planting (965 g) (Table 3). On the other hand, there was a significant $(\mathrm{P}<0.05)$ difference among the three sweet potato varieties in the mass of storage roots per plant. Varieties Ligwalagwala and Kenya-white had significantly higher mass of storage roots per plant of $1169 \mathrm{~g}$ and $1139 \mathrm{~g}$, respectively, while variety Lamngititi had the lowest mass of storage roots per plant (Table 3).

\subsection{Diameter of storage root}

Storage root diameter was not significantly affected due to methods of planting, but the vertical method of planting had thicker tubers of $5.37 \mathrm{~cm}$ as compared to the horizontal method which had $5.15 \mathrm{~cm}$ (Table 3). However, there was a significant $(\mathrm{P}<0.05)$ difference in storage root diameter of the three sweet potato varieties. Varieties Kenya-white and Ligwalagwala had significantly thicker tubers of $5.79 \mathrm{~cm}$ and $5.58 \mathrm{~cm}$, respectively, than variety Lamngititi (Table 3). The interaction effect of planting method and varieties was not significant on storage root diameter.

\subsection{Length of storage root}

The main effects of planting method and varieties as well as their interaction were not significant on the storage root length. However, the vertical method of planting had longer tubers of $18.69 \mathrm{~cm}$ than the horizontal method of planting $(18.2 \mathrm{~cm})$ (Table 3). Among the varieties, Kenya-white had the longest tubers of $19.57 \mathrm{~cm}$ while Ligwalagwala had shortest storage root of $17.54 \mathrm{~cm}$ (Table 3 ).

\subsection{Storage root yield}

There was no significant difference in the storage root yield between the horizontal and vertical method of plantings (Table 4). The vertical planting had relatively higher storage root yield ( 9.72 tonnes/ha) than the horizontal planting ( 9.62 tonnes/ha). However, the sweet potato varieties showed significant $(\mathrm{P}<0.05)$ differences in the storage root yield. Variety Ligwalagwala had significantly the highest yield of 12.01 tonnes/ha while variety Kenya-white had the lowest storage root yield of 7.48 tonnes/ha (Table 3). The interactions of the planting methods and varieties was not significant in the storage root yield.

Table 3 Effects of planting methods and sweet potato varieties on yield components and yield of sweet potato

\begin{tabular}{|l|l|l|l|l|l|}
\hline Treatment & $\begin{array}{l}\text { Number of } \\
\text { storage roots } \\
\text { per plant }\end{array}$ & $\begin{array}{l}\text { Mass of storage } \\
\text { roots per plant } \\
\text { (g) }\end{array}$ & $\begin{array}{l}\text { Diameter of } \\
\text { storage roots } \\
\text { (cm) }\end{array}$ & $\begin{array}{l}\text { Length } \\
\text { storage of } \\
\text { (cm) }\end{array}$ & $\begin{array}{l}\text { Storage root } \\
\text { yield } \\
\text { (tonnes/ha) }\end{array}$ \\
\hline Planting methods & \multicolumn{5}{|l|}{} \\
\hline Horizontal & 5.89 & 965 & 5.15 & 18.2 & 9.64 \\
\hline Vertical & 5.56 & 5.39 & 18.69 & 9.72 \\
\hline LSD (0.05) & $\mathrm{ns}$ & $\mathrm{ns}$ & $\mathrm{ns}$ & $\mathrm{ns}$ \\
\hline Varieties & 1103 & $\mathrm{n}$ & $7.48 \mathrm{~b}$ \\
\hline Kenya-white & $4.37 \mathrm{~b}$ & $1116 \mathrm{a}$ & 19.57 & $12.01 \mathrm{a}$ \\
\hline Ligwalagwala & $6.47 \mathrm{a}$ & $1137 \mathrm{a}$ & $5.58 \mathrm{a}$ & 17.54 & $9.56 \mathrm{ab}$ \\
\hline Lamngititi & $6.33 \mathrm{a}$ & $796 \mathrm{~b}$ & $4.45 \mathrm{~b}$ & 18.23 & 3.301 \\
\hline LSD (0.05) & 0.933 & 242.8 & 0.727 & $\mathrm{~ns}$ & 26.5 \\
\hline CV (\%) & 12.7 & 18.3 & 12.1 & \\
\hline
\end{tabular}




\section{Discussion}

\subsection{Vine length}

Vertical method of planting had higher mean vine length than the horizontal method from 6 to 12 weeks after planting. In contrast to this result, Pakkies et al. [9] reported that horizontal orientation of cuttings resulted in consistently longer vine lengths compared with vertical orientation. Similarly, Parwada et al. [14] reported higher mean vine lengths in horizontally planted cuttings followed by inclined cuttings and lastly by vertical cuttings.

There was a significant difference in vine lengths of the sweet potato varieties where variety Ligwalagwala had the highest vine length. The differences in vine length due to variety can be attributed to the inherent genetic difference. In agreement to this result, Kapinga et al. [15] and Egbe et al. [16] reported variation in vine length and attributed it to differences in genetic make-up of the sweet potato varieties.

\subsection{Number of branches}

The vertical planting method had higher number of branches per plant than horizontal method of planting. This could be due to the fact that branch formation depends mostly on vine length of the plant since the vertical method had longer vines as compared to the horizontal method [14]. There was no significant difference in the number of branches per plant among the sweet potato varieties. Factors such as genetic potential of variety, number of available sprouts at planting and sprout damage may affect branching. In contrast with this result, Wubanechi [17] reported significant difference among the sweet potato varieties where varieties Burtukanne and Jari had higher number of branches of 8.36 and 8.25 per plant, respectively, than variety Belella.

\subsection{Number of leaves}

Variety Lamngititi in horizontal planting produced significantly highest number of leaves per plant at 10 and 12 WAP. This might have resulted due to the fact that horizontally planted cuttings being evenly spaced and having a larger area from which to tap water and nutrients towards vine growth thereby producing more leaves. The variation of the number of leaves is a genetic character [18]. In line with this result, Saitama et al. [19] reported significant differences in leaf area index among 10 varieties of sweet potato that ranged from 3.15 to 4.67. The number of leaves is believed to depend on the number of branches and internode length.

\subsection{Number of storage roots}

The horizontal method produced more number of storage roots compared to the vertical method of planting. The results are consistent with that of Kunene [8]; and Pakkies et al. [9] who also reported that the horizontal method of planting having a high number of tubers per plant compared to other methods of planting though the difference was not significant. Pakkies et al. [9] Further reported that horizontally planted cuttings developed adventitious roots at the callus tissues at the cut vine end with ample space for full expansion of roots. Vertically planted cuttings, however, only formed roots downwards with little space to draw water and nutrients resulting in lower number of tubers. Varieties Ligwalagwala and Lamngititi had significantly higher number of tubers per plant than variety Kenya-white which might be due to the inherent genotypic differences among the varieties in root formation. Several studies showed that the use of different varieties showed significantly differences in the number of storage roots per plant which could be due to number of sub vines, leaves, leaf area and partitioning in a particular genotype [20]; [21]. In agreement with this result, Wubanechi [17] reported significant difference among the sweet potato varieties where variety Burtukunne produced the highest average marketable storage roots number per plant (3.71) than varieties Belella (2.66) and Jari (2.09).

\subsection{Mass of storage roots}

The vertical method of planting had a larger mass of storage roots per plant compared to the horizontal method. In line with this result, Campbell [10] reported that the vertical method of planting had higher yields in terms of mass. Varieties Ligwalagwala and Kenya-white had significantly higher mass of tubers per plant than variety Lamngititi. This could be attributed to differences in source-sink relationships [22]. Some sweet potato varieties have been reported to partition more towards shoot production while others towards storage root production [23]. This could have been true for variety Lamngititi which had longer vines and highest number of leaves per plant but produced low storage roots when compared to variety Kenya-white which had shorter vines and lower number of leaves per plant yet produced a higher mass of tubers. 


\subsection{Storage root diameter}

The vertical method of planting had the thickest tubers per plant. According to Laurie and Niederwieser [23] the orientation of cuttings at planting had no significant effect on the formation of thick roots formed. Burying cuttings deeper however, would result in formation of small sized storage roots due to the slow rate of root development from the hard pans [23] which might have been the case for horizontally planted cuttings. In contrast with this result, Parwada et al. [14] obtained thicker roots on horizontally planted cuttings as compared to vertically planted cuttings and attributed this to positive geotropism of roots which resulted in horizontally planted cuttings, having ample space for free swelling, as compared to vertically planted cuttings where roots grew closer together with limited space for expansion. Varieties Kenya-white and Ligwalagwala had significantly higher storage root diameter than variety Lamngititi as it was true for mass of storage roots. This could be due to the developmental process associated with the expression of several genes which are influenced by several environmental factors [25].

\subsection{Storage root length}

The vertical method of planting had longer storage roots as compared to the horizontal method of planting. This could be due to the horizontally planted sweet potato having been buried at a deeper planting depth since it had to be done across the ridge. This might have resulted in the formation of shorter storage roots due to the slow rate of root development from the hard pans [23]. This could have been also because the sweet potato on the vertical method had more leaves implying that photosynthesis rate was high leading to more sugars for the storage roots hence their length growth [24]. Variety Kenya-white had the longest average tuber length than the other varieties which might be due to its inherent genetic characteristics. This result is in line with the findings of Mngomezulu [27] who obtained longer storage roots for variety Kenya-white as compared to variety Ligwalagwala.

\subsection{Storage root yield}

The vertical method of planting had a higher storage root yield as compared to the horizontal method of planting. Parwada et al. [14] postulated that the position of a cut vine at planting determines the direction of adventitious roots which affects the extraction of water and nutrients from soil, and this in turn determines the length of stems, branches per plant and ultimately yield. In conformity with this result, Campbell [19] reported higher yield for vertical orientation. In contrast to this result, Kunene [8]; and Pakkies et al. [9] obtained higher storage root yield from horizontal method than the vertical method of planting. Variety Ligwalagwala had significantly highest storage root yield as compared to the other varieties. Similar results were reported by Nxumalo et al. [27] who reported higher yields for Ligwalagwala than Kenya White. This can be attributed to the highest number of storage roots and mass of storage roots per plant produced by the variety. The variations in the yield of the three varieties could be due to the translocation of photosynthates to storage roots which differs from one variety to another, depending on the sink -source strength relationship of an individual variety [22]; [9]

\section{Conclusion}

The horizontal and vertical methods of planting did not show significant differences in most growth and yield parameters of three sweet potato varieties. However, the vertical method of planting outperformed the horizontal method in vine length, number of branches, mass of storage roots and storage root yield. Among the sweet potato varieties, Ligwalagwala had the highest number of storage roots, mass of storage roots and storage root yield. Thus, either horizontal or vertical method of planting and variety Ligwalagwala can be used to increase the productivity of sweet potato in the study area. However, to reach at a conclusive recommendation, the experiment has to be repeated over more years.

\section{Compliance with ethical standards}

\section{Acknowledgments}

The authors are grateful to the Taiwan Technical Mission in Eswatini for providing vines for the three sweet potato varieties used in this trial.

\section{Disclosure of conflict of interest}

The authors hereby declare there is no conflict of interests. 


\section{References}

[1] Birksew A, Dikale G. The Evaluation of Growth Performance of Sweet Potato (Ipomoea batatas L.) Awassa Var. by Using Different Type of Vine Cuttings. Evaluation. 2016; 54.

[2] Tavva S, Nedunchezhiyan M. Global status of sweet potato cultivation. Fruit Vegetable Cereal Science Biotechnology. 2012; 6: 143-147.

[3] CIP (International Potato Center). 2010. Sustainable sweet potato production and utilization in Orissa, India. Proceedings of a workshop and training held in Bhubaneswar, Orissa, India, 17-18 Mar 2010. Bhubaneswar, India.

[4] Ukom AN, Ojimelukwe PC, Okpara DA. Nutrient composition of selected sweet potato [Ipomoea batatas (L.) Lam] varieties as influenced by different levels of nitrogen fertilizer application". Pakistan Journal of Nutrition. 2009; 8(11): 1791 - 1795.

[5] Ossom EM, MH Nxumalo, FM Badejo. Evaluating different traditional storage methods on the shelf life of sweet potato tubers in Swaziland. Final Report submitted to UNISWA Research Board, University of Swaziland, Kwaluseni, Swaziland. 2004.

[6] Edje OT, Ossom EM. Crop Science Handbook Second Edition. Blue Moon Publishers, Manzini, Swaziland. 2016.

[7] FAOSTAT. Crop Statistical Database. 2019. http://fenix.fao.org/faostat/internal/en/\#data. 14/05/2021.

[8] Kunene NM. Effects of vine orientation methods on the yield and quality of two sweet potato [Ipomoea batatas (L)] varieties. Unpublished B. Sc. Final Year Research Report. University of Swaziland, Luyengo Campus, Luyengo, Swaziland. 2015.

[9] Pakkies Z, van Jaarsveld CM, Mavengahama S. Effect of variety and cutting orientation at planting on sweet potato growth and yield in the Verulam area, South Africa. South African Journal of Plant and Soil. 2019; 36(1): 73-75.

[10] Campbell C. Farmers encouraged to use vertical method to plant sweet potatoes. NOW Grenada. 2019.

[11] Murdoch G. Soils and land capability in Swaziland. Swaziland Ministry of Agriculture, Mbabane, Swaziland. 2000.

[12] Ossom EM. Influence of sweet potato/maize association on ecological properties and crop yields in Swaziland. International Journal of Agriculture and Biology. 2010; 12(4): 481-488.

[13] GenStat. GenStat Procedure Library Release.18th edition. VSN International Ltd. 2015.

[14] Parwada C, Gadzirayi CT, Sithole AB. Effect of ridge height and planting orientation on Ipomea batatas (sweet potato) production. Journal of Agricultural Biotechnology and Sustainable Development. 2011; 3(4): 72- 76.

[15] Kapinga R, Tumwegamire S, Ndunguru J, Andrade MI, Agili S, Mwanga ROM, Laurie S, Dapaah H. Catalogue of orange-fleshed sweet potato varieties for Sub-Saharan Africa. International Potato Center (CIP), Lima, Peru. 2010; 40.

[16] Egbe OM. Relative Performance of Three Sweet Potato Varieties in Sole and Intercrop. Systems in Southern Guinea Savanna Ecology of Nigeria. Global Journal of Science Frontier Research Agriculture \& Biology. 2012; 12(3): 36-43.

[17] Wubanechi S. Effect of planting density on growth and yield of sweet potato [Ipomoea batatas (L.) Lam] varieties in Habru district, northern Ethiopia. Msc thesis. Haramaya University, Ethiopia. 2014.

[18] Nedunchezhiyan M, Byju G, Naskar SK. Sweet potato (Ipomoea batatas L.) as an intercrop in a coconut plantation: growth, yield and quality. Journal of Root Crops. 2007; 33(1): 26-29.

[19] Saitama A, Nugroho A, Widaryanto E. Yield response of ten varieties of sweet potato (Ipomoea batatas L.). J. Degrade. Min. Land Manage. 2017; 4(4): 919-926.

[20] Villordon A, LaBonte D, Firon N. Development of a simple thermal time method for describing the onset of morpho-anatomical features related to sweet potato storage root formation. Scientia Horticulturae. 2009; 121(3): 374-377.

[21] Gajanayake B, Reddy KR, Shankle MW, Arancibia RA. Growth, developmental, and physiological responses of two sweet potato (Ipomoea batatas L.) varieties to early season soil moisture deficit. Scientia Horticulturae. 2014; 168: 218-228. 
[22] Lebot V. Sweet potato. In Root and tuber crops. Springer, New York, NY. 2010; 97-125

[23] Laurie SM, Niedwieser S. Sweet potato in perspective. Guide to sweet potato production in South Africa. 2004; 16.

[24] Hossain MD, Rabbani MG, Mollah MLR. Genetic variability, correlation and path analysis of yield contributing characters in sweet potato (Ipomoea batatas L). Pakistan Journal of Scientific and Industrial Research. 2000; 43(5): 314-318.

[25] Ravi V, Naskar SK, Makeshkumar T, Babu B, Krishnan BP. Molecular physiology of storage root formation and development in sweet potato (Ipomoea batatas (L.) Lam.). Journal of Root Crops. 2009; 35(1): 1-27.

[26] Mngomezulu TA. Evaluating agronomic traits of sweet potato (Ipomoea batatas L.) genotypes in Swaziland. Unpublished B. Sc. Final Year Research Report. University of Swaziland, Luyengo Campus, Luyengo, Swaziland. 2018.

[27] Nxumalo K, Mabuza M, Dlamini B. Effect of inorganic fertilisers on growth, yield and organoleptic properties of two sweet potato (Ipomoea batatas L.) cultivas. International Journal of Agriculture, Environment and Bioresearch. 2021; 6(3): 1-16. 